IdeAs

Idées d'Amériques

$14 \mid 2019$

Populismes dans les Amériques

\title{
"I hear America singing, I see America dancing": la compagnie new-yorkaise DanceVisions célèbre Walt Whitman et Isadora Duncan
}

\section{Adeline Chevrier-Bosseau}

\section{(2) OpenEdition Journals}

Édition électronique

URL : http://journals.openedition.org/ideas/6386

DOI : $10.4000 /$ ideas.6386

ISSN : 1950-5701

Éditeur

Institut des Amériques

Référence électronique

Adeline Chevrier-Bosseau, " "I hear America singing, I see America dancing": la compagnie newyorkaise DanceVisions célèbre Walt Whitman et Isadora Duncan », IdeAs [En ligne], 14 | 2019, mis en ligne le 01 octobre 2019, consulté le 09 novembre 2019. URL : http://journals.openedition.org/ideas/ 6386 ; DOI : 10.4000/ideas.6386

Ce document a été généré automatiquement le 9 novembre 2019.

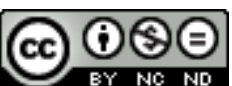

IdeAs - Idées d'Amériques est mis à disposition selon les termes de la licence Creative Commons Attribution - Pas d'Utilisation Commerciale - Pas de Modification 4.0 International. 


\title{
"I hear America singing, I see America dancing": la compagnie new-yorkaise DanceVisions célèbre Walt Whitman et Isadora Duncan
}

\author{
Adeline Chevrier-Bosseau
}

1 Dans le cadre de l'événement "Walt Whitman @200", la compagnie Dance Visions a donné une représentation de son ballet "I hear America singing, I see America dancing" dans la maison familiale des Whitman à Long Island le 27 juillet 2019, en l'honneur du bicentenaire de Walt Whitman et du $141^{\mathrm{e}}$ anniversaire de la danseuse et chorégraphe Isadora Duncan. Le ballet, qui allie le mouvement naturel prôné par Duncan et la poésie de Walt Whitman, rend hommage à ces deux artistes dont l'œuvre et l'influence ont à jamais bouleversé le paysage poétique et chorégraphique américain.

2 La compagnie Dance Visions, fondée par Beth Jucovy (qui en est également la directrice artistique) se spécialise dans le style Duncan et œuvre à perpétuer la tradition chorégraphique et la philosophie de la danse de cette pionnière de la danse moderne. Beth Jucovy a appris les ballets d'Isadora Duncan, ainsi que toute sa technique et son esthétique si particulière, auprès d'Anna Duncan - une ancienne "Isadorable ", comme étaient surnommées les élèves de Duncan - puis auprès de Julia Levien et Hortense Kooluris, qui font partie de la deuxième génération de danseuses spécialisées dans le style Duncan. Outre les représentations et les créations chorégraphiques, la compagnie a une fonction de conservation et de transmission du matrimoine : il faut ici rappeler que la danse américaine moderne doit beaucoup aux femmes, à des artistes engagées comme Loïe Fuller, Isadora Duncan, Ruth Saint Denis, Martha Graham ou Doris Humphrey, qui ont révolutionné la danse, repensé toute l'approche au corps et au mouvement, et fondé une tradition de la transmission d'une certaine philosophie de la danse américaine en créant leurs écoles. En œuvrant pour la conservation de l'école Duncan, Dance Visions s'inscrit directement dans cette tradition et rend hommage au matrimoine de la danse américaine. 
Née à San Francisco en 1877, Isadora Duncan se considérait comme « la fille spirituelle de Walt Whitman »; dans son autobiographie, Duncan explique que l'inspiration pour sa philosophie de la danse - une danse "naturelle ", qui ne restreint pas le corps mais en célèbre la beauté naturelle et le mouvement non entravé - lui est venue de la contemplation de la beauté sauvage du territoire américain :

I have discovered the dance. I have discovered the art which has been lost for two thousand years. (...) I bring you the dance. I bring you the idea that is going to revolutionize our entire epoch. Where have I discovered it? By the Pacific Ocean, by the waving pine-forests of Sierra Nevada. I have seen the ideal figure of youthful America dancing over the top of the Rockies. The supreme poet of our country is Walt Whitman. I have discovered the dance that is worthy of the poem of Walt Whitman. I am indeed the spiritual daughter of Walt Whitman. For the children of America I will create a new dance that will express America. (Duncan I., 2013 : 21-22)

4 Comme Whitman, Duncan célèbre la jeunesse et la vigueur du corps américain, ainsi que la majesté de son territoire. Tout comme son père spirituel aime à offrir des images de corps en mouvement, de corps d'ouvriers qui travaillent (on pense par exemple au charpentier, au maçon ou au cordonnier en plein labeur du poème «I Hear America Singing", auquel fait référence le titre du ballet et que Duncan reprend dans son fameux «I See America Dancing »), la danse que Duncan imagine pour l'avenir est une danse qui rejette une certaine tradition aristocratique de la danse et honore la noblesse $\mathrm{du}$ corps naturel. Cette dimension démocratique, très américaine, est commune à Whitman et Duncan; dans Leaves of Grass, la danse telle qu'elle se pratiquait dans la bourgeoisie ou la noblesse au XIX ${ }^{\mathrm{e}}$ siècle - selon des codes genrés et sociaux stricts - est vue comme un divertissement décadent et malsain dans la $7^{\mathrm{e}}$ section de « Song of the Exposition » par exemple :

Away with old romance!

Away with novels, plots and plays of foreign courts,

Away with love-verses sugar'd in rhyme, the intrigues, amours of idlers,

Fitted for only banquets of the night where dancers to late music slide,

The unhealthy pleasures, extravagant dissipations of the few,

With perfumes, heat and wine, beneath the dazzling chandeliers. (Whitman W., $2002: 170)$

Cette danse, artificielle, bourgeoise, anti-démocratique («the extravagant dissipations of the few ») et malsaine, qui ne se danse que dans l'atmosphère étouffante des salles de bal, est vivement condamnée par celui qui s'auto-proclame le "poète du corps » dans «Song of Myself ». Au contraire, quand Whitman représente les classes populaires qui dansent, leur danse est toujours spontanée et joyeuse, comme dans la $15^{\mathrm{e}}$ section de "Song of Myself» ("The bugle calls in the ball-room, the gentlemen run for their partners, the dancers bow to each other ", Leaves of Grass, 37) ; les bourgeois dansent dans des salles de bal confinées, tandis que les ouvriers dansent le plus souvent dehors (dans « Native Moments », " Our Old Feuillage » ou « We two Boys Together Clinging », par exemple). La valse qui régnait dans les salles de bal en Europe et aux États-Unis à l'époque disparait bien souvent au profit de danses populaires plus libres et dynamiques comme la gigue (" Proud Music of the Storm », Leaves of Grass, 341) ou les danses mystiques, dionysiaques, énumérées dans le même poème. Dans son essai « La Danse de l'avenir » (1903) ${ }^{1}$, Isadora Duncan rejette quant à elle toute la tradition noble du ballet européen, cet art « aristocratique » prend sa source à la cour de Louis XIV, qui entrave et déforme les corps avec ses codes rigides: 
The school of the ballet today, vainly striving against the natural laws of gravitation or the natural will of the individual, and working in discord in its form and movement with the form and movement of nature, produces a sterile movement which gives no birth to future movements, but dies as it is made (...) look - under the skirts, under the tricots are dancing deformed muscles. Look still farther underneath the muscles are deformed bones. A deformed skeleton is dancing before you. This deformation through incorrect dress and incorrect movement is the result of the training necessary to the ballet. The ballet condemns itself by enforcing the deformation of the beautiful woman's body! (Copeland R. et M. Cohen, $1983: 263$ )

6 Tout comme Whitman admire les «membres souples" et la démarche «libre et élastique » de la jeune squaw dans la $6^{\mathrm{e}}$ section de « The Sleepers ${ }^{2}$, Duncan écrit :

The movements of the savage, who lived in freedom in constant touch with Nature, were unrestricted, natural and beautiful. Only the movements of the naked body can be perfectly natural. Man, arrived at the end of civilization, will have to return to nakedness, not to the unconscious nakedness of the savage, but to the conscious and acknowledged nakedness of the mature Man, whose body will be the harmonious expression of his spiritual being. (Ibid.)

Duncan s'inspire également de Whitman dans sa conception de la pédagogie; dans "Song of Myself», Whitman convoque l'image d'un pédagogue-élève, en perpétuel apprentissage, dans la $16^{\mathrm{e}}$ section ("A learner with the simplest, a teacher of the thoughtfullest, / A novice beginning yet experient of myriads of seasons ", Leaves of Grass, 40) et prône une vision agonistique de l'enseignement qui ne soumet pas l'élève au maître, mais l'encourage au contraire à le dépasser, dans la $47^{\mathrm{e}}$ section :

«I am the teacher of athletes,

He that by me spreads a wider breast than my own proves the width of my own,

He most honors my style who learns under it to destroy the teacher. " (Whitman W., $1955: 73)$

De même, Duncan souhaite libérer la créativité et les corps de ses élèves :

My intention is, in due time, to found a school, to build a theatre where a hundred little girls shall be trained in my art, which they, in their turn, will better. In this school I shall not teach the children to imitate my movements, but to make their own. I shall not force them to study certain definite movements; I shall help them to develop those movements which are natural to them. Whosoever sees the movements of an untaught little child cannot deny that its movements are beautiful. They are beautiful because they are natural to the child. (Copeland R. \& Cohen M., 1983 : 263-64)

10 Whitman, le « poète du corps ", aimait la danse, qui apparait dans Leaves of Grass comme l'exultation du corps en mouvement, et incarne également pour le poète la démocratie (tous les corps en mouvement sont beaux), et ce que Jimmie Killingsworth a appelé la " moralité physique » whitmanienne ${ }^{3}$ - un rejet de l'oisiveté bourgeoise et de ses codes sociaux en faveur d'une saine valorisation du corps en mouvement. La danse incarne également le lyrisme whitmanien, la fluidité identitaire et corporelle du sujet lyrique dans Leaves of Grass ${ }^{4}$. Il n'est donc pas surprenant que celui qui a chanté l'Amérique et le corps américain ait été une telle source d'inspiration pour les pionniers de la danse américaine moderne; outre Duncan, Whitman apparaît comme un modèle d'américanité et d'innovation formelle chez Ted Shawn et Lincoln Kirstein, une figure tutélaire pour toute une nouvelle génération de danseurs, de l'école Denishawn à 
Martha Graham, et sa quête démocratique trouve un écho dans les travaux du New Dance Group dans les années 1930.

Le ballet créé par Beth Jucovy et Shirley Romaine rend hommage à l'esprit novateur de Duncan et Whitman, alternant soli et tableaux de groupe, tous précédés d'une lecture d'un poème de Whitman. Les danseurs étaient accompagnés au piano par Mark Fiedler, qui a joué une sélection majoritairement composée de valses par Chopin, Brahms, Schubert, Strauss et Glück. Les divers tableaux dansent la nature, les éléments, le corps naturel et les émotions. " Ménade ", interprétée par Louisa Cathcart sur la valse n ${ }^{\circ} 11$ en si mineur de Brahms (Opus 39) danse le flux continuel de l'univers qui converge vers le sujet dans la section 20 de "Song of Myself» («I know I am solid and sound, / To me the converging objects of the universe perpetually flow », Leaves of Grass, 42), et incarne à la fois l'ancrage terrien du sujet lyrique et la fluidité de son être et de ses identifications multiples dans une danse dionysiaque tout autant whitmanienne que duncanienne.

Louisa Cathcart in « Maenad »

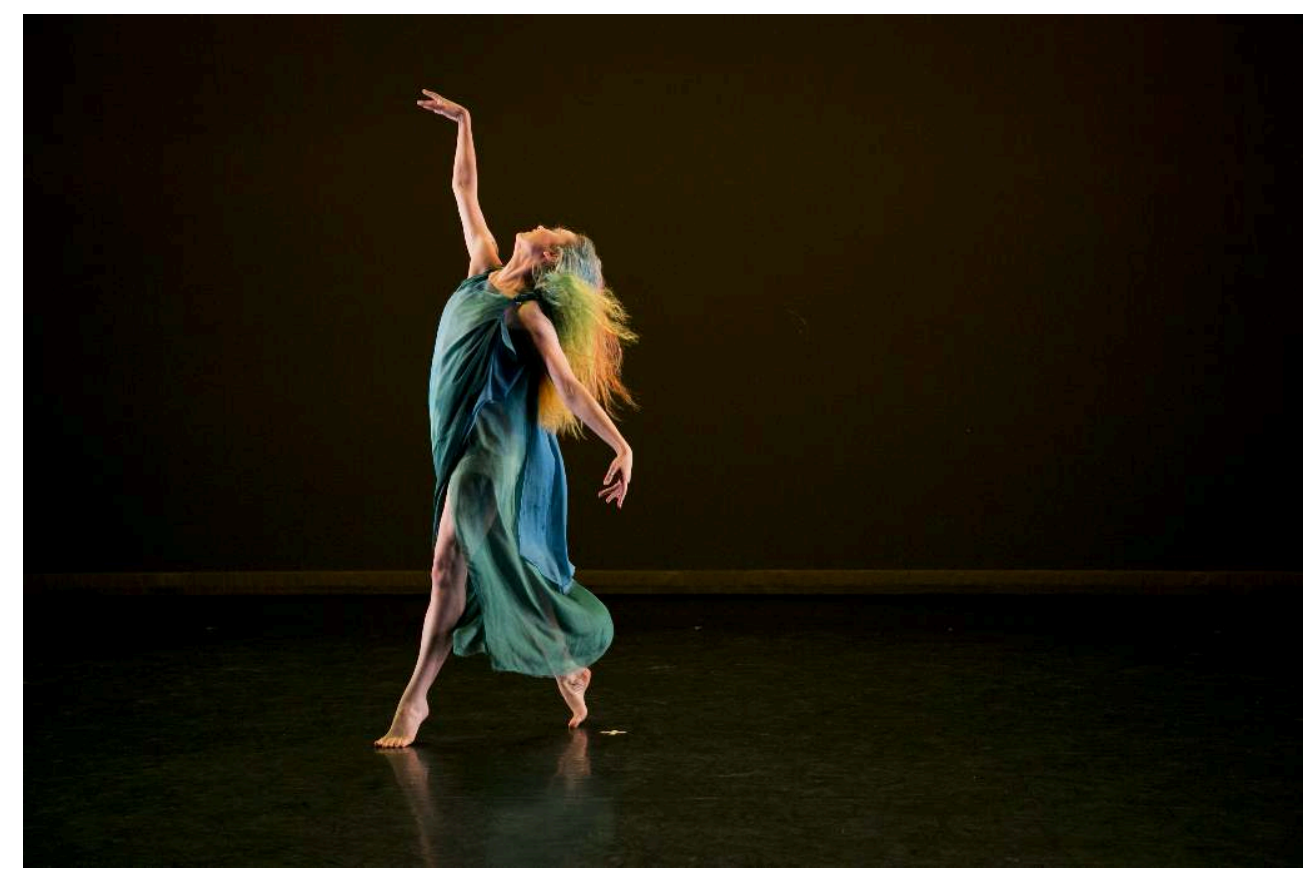

(c) Whitney Browne

12 Le tableau suivant, intitulé " Gypsy », interprété par Vanessa Ferranti sur la valse en mi mineur (Opus 39, $\mathrm{n}^{\circ} 4$ ) de Brahms, est précédé d'une lecture de la célèbre section 21 de "Song of Myself » qui s'ouvre sur la déclaration «I am the poet of the Body ; / And I am the poet of the Soul» (Leaves of Grass, 43). Dans le plus pur style Duncan, la chorégraphie joue de l'envol vaporeux du costume, inspiré des toges fluides de la Grèce antique ; la "gitane » est vêtue de rouge, et sa danse célèbre la sensualité de la terre et du corps féminin libre de toute entrave que chante Whitman dans cette section de Leaves of Grass :

I am the poet of the woman the same as the man;

And I say it is as great to be a woman as to be a man;

And I say there is nothing greater than the mother of men.

(...) 
I call to the earth and sea, half-held by the night. (...)

Smile, O voluptuous, cool-breath'd earth!

Earth of the slumbering and liquid trees;

Earth of departed sunset! earth of the mountains, misty-topt!

Earth of the vitreous pour of the full moon, just tinged with blue!

Earth of shine and dark, mottling the tide of the river!

Earth of the limpid gray of clouds, brighter and clearer for my sake!

Far-swooping elbow'd earth! rich, apple-blossom'd earth!

Smile, for your lover comes! (Whitman W., 2002 : 43)

Vanessa Ferranti in « Gypsy »

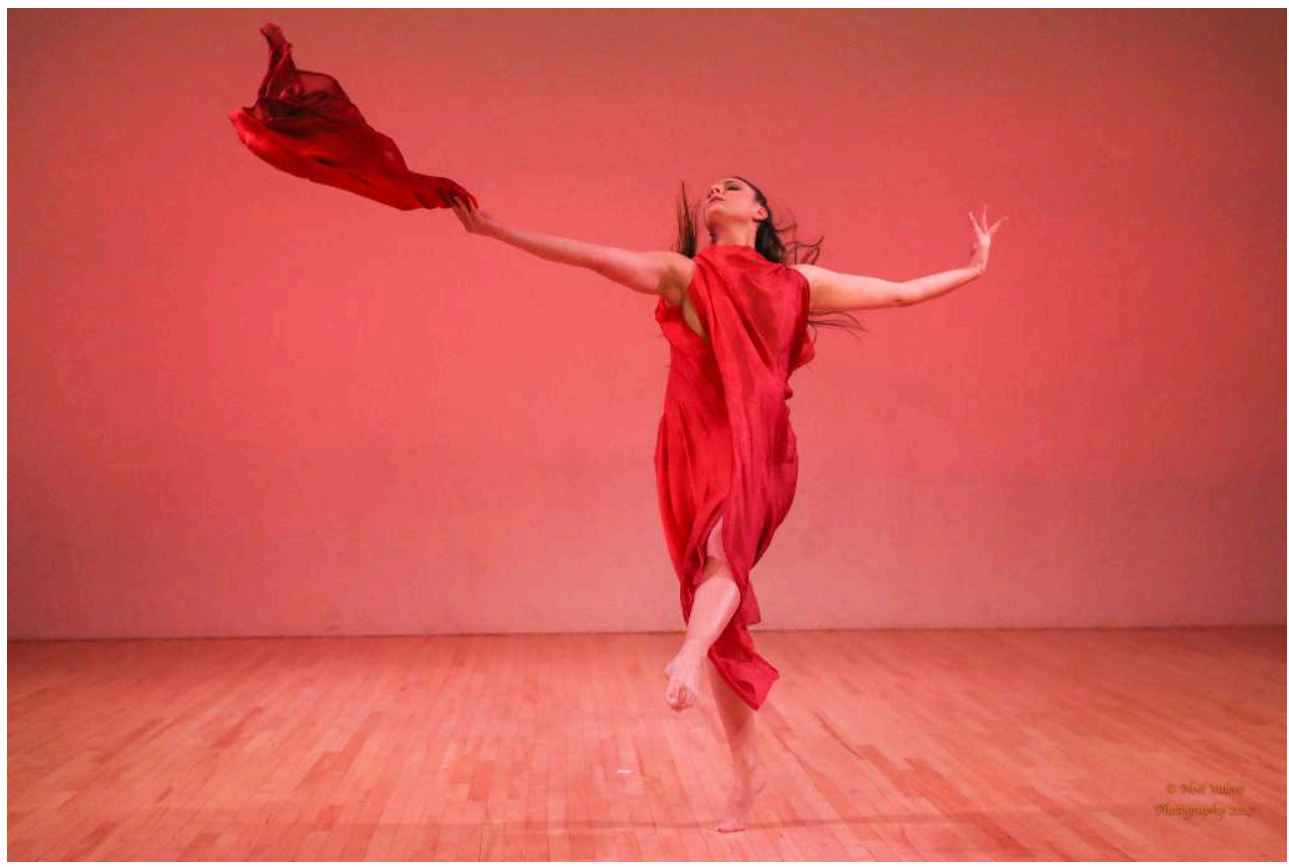

(c) Noel Valero

Par son aspect joueur et séducteur, la danse de cette " gitane " rappelle en outre les danses espagnoles qui étaient beaucoup dansées sur scène au XIX ${ }^{\mathrm{e}}$ siècle particulièrement par Fanny Elssler, la «danseuse païenne » comme la surnommait Théophile Gautier, qui avait fait de la «cachucha »sa spécialité et avait connu un immense succès lors de sa tournée américaine en 1840-42. Whitman, qui mentionne ces danses espagnoles dans la section 3 de "Salut au Monde ${ }^{5}$, avait même créé un personnage de danseuse espagnole inspiré d'Elssler dans The Life and Adventures of Jack Engle. La "gitane » incarne cette "terre voluptueuse » que chante Whitman, cette féminité opulente et délibérément terrienne: comme Martha Graham après elle, Duncan dansait pieds nus et enseignait à ses élèves à faire de même, car c'est ainsi que le corps du danseur est réellement ancré dans le sol, dans la terre, et en contact avec les éléments naturels. Ce rapport d'ancrage du corps en mouvement à la terre, cette osmose naturelle entre le corps humain et la terre, font bien évidement penser à l'enfant pieds nus dans "Out of the Cradle Endlessly Rocking " ${ }^{6}$ ou à la réaction physique, viscérale, à la musique du locuteur dans la section 26 de "Song of Myself » qui se représente pieds nus dans les vagues, dans une posture très duncanienne ${ }^{7}$. Le ballet «I hear America singing, I see America dancing » comporte un tableau intitulé « Narcissus », dansé par Nam Jiemvitayanukoon ${ }^{8}$ sur la valse en ré bémol majeur, opus 
64, $\mathrm{n}^{\circ} 1$ de Chopin, précédé d'une lecture de "Not heat flames up and consumes ", extrait de « Calamus » (Leaves of Grass, 106-107).

Nam Jiemvitayanukoon in « Narcissus »

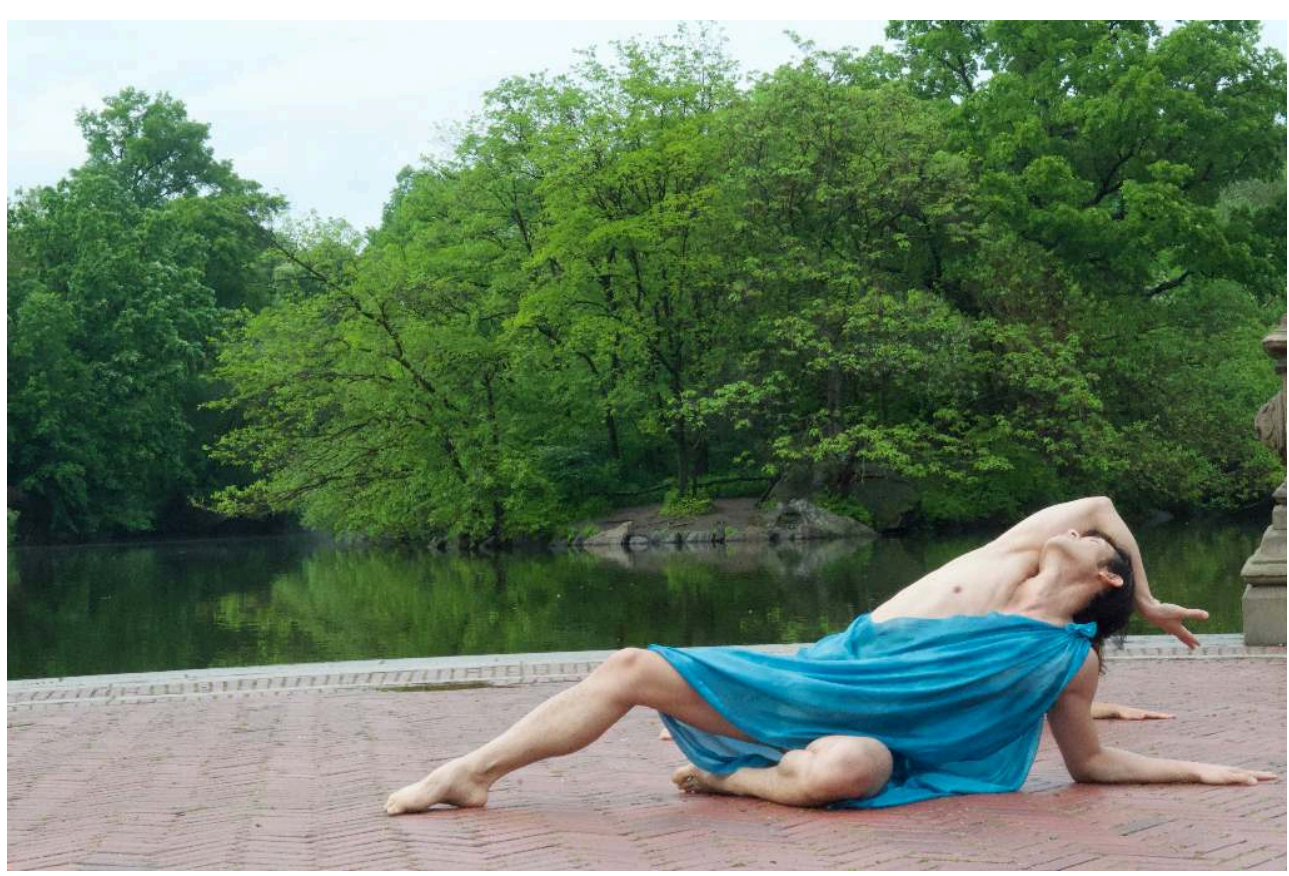

(c) Melanie Futurion. At Central Park, Bethesda Fountain

Outre le rapport aux éléments (eau, feu) présents dans le poème de Whitman et inhérents au style Duncan, la chorégraphie célèbre la sensualité du corps masculin - un thème cher à Walt Whitman, qui dans Leaves of Grass représente surtout des hommes qui dansent, en rupture totale avec les conventions de son époque. Whitman écrit en effet à une période qu'on a surnommée dans l'histoire de la danse "l'âge d'or de la ballerine ", tant les ballets du xix ${ }^{e}$ siècle mettent la danseuse sur pointes au centre de la chorégraphie (tandis que son partenaire se voit relégué à un rôle de soutien pour les portés) et sa fascination pour le corps masculin qui danse est à contre-courant des conventions de son époque.

Le titre du ballet de Jucovy et Romaine évoque cette déclaration de Duncan dans son autobiographie :

In a moment of prophetic love for America Walt Whitman said: "I hear America singing," and I can imagine the mighty song that Walt heard, from the surge of the Pacific, over the plains, the voices rising of the vast Choral of children, youths, men and women, singing Democracy.

When I read this poem of Whitman's I, too, had a Vision-the Vision of America dancing a dance that would be the worthy expression of the song Walt heard when he heard America singing. This music would have a rhythm as great as the exhilaration, the swing or curves of the Rocky Mountains. (...) it would be like the vibration of the American soul striving upward, through labour to harmonious life. (Duncan I., 2013 : 304-305)

16 Fidèle à l'esprit de Duncan et à celui de Whitman, «I hear America singing, I see America dancing » danse le corps américain libre, son rapport organique au territoire américain, ainsi que la démocratie incarnée dans ses corps en mouvement libérés de toute contrainte. 
Dancers at the Walt Whitman Birthplace after the performance

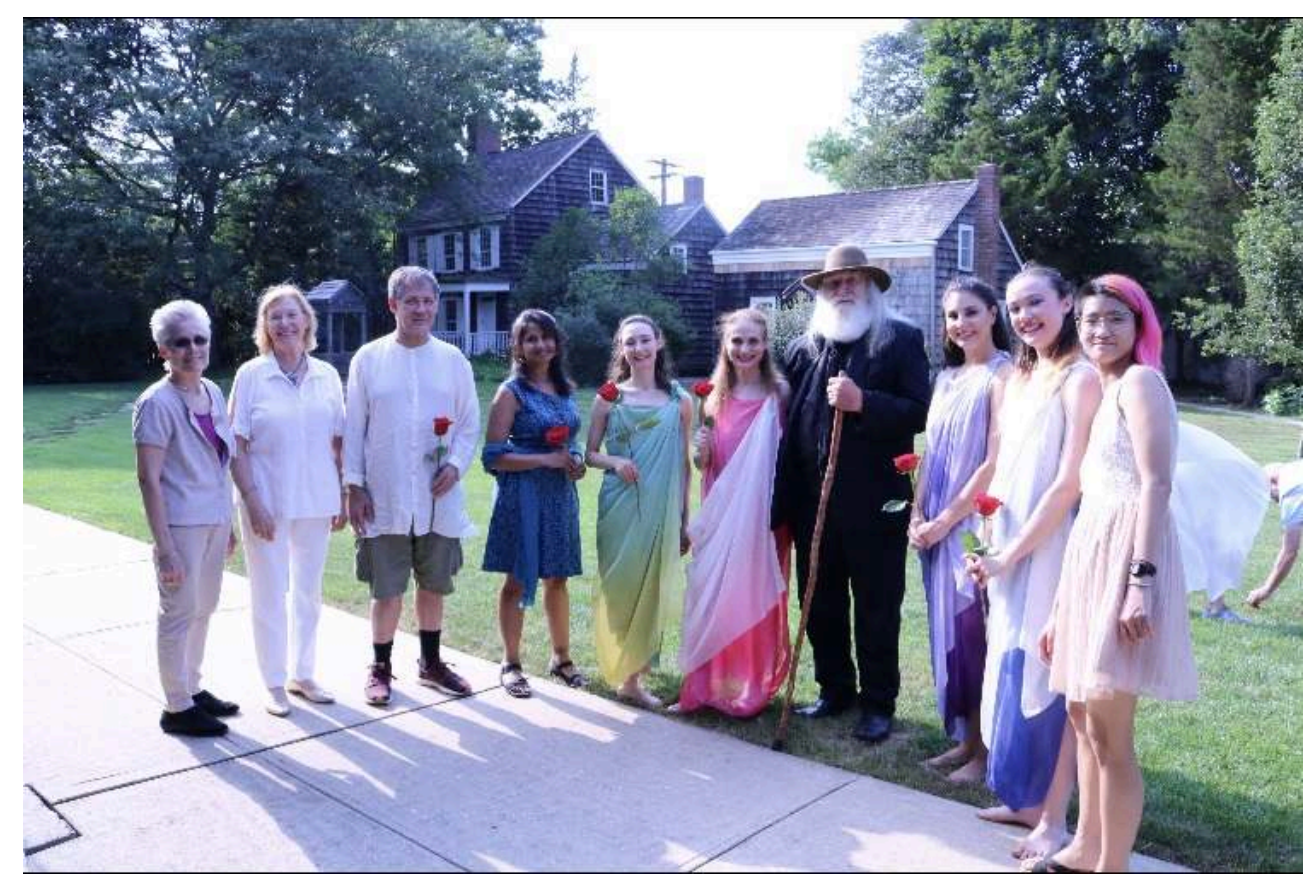

\section{BIBLIOGRAPHIE}

Chevrier-Bosseau, Adeline, « Dance in Walt Whitman's Leaves of Grass: Haptic Connectedness and Lyric Choreography », in Agnès Derail et Cécile Roudeau (dir.), Whitman, Feuille à feuille, Paris, Presses de l'ENS, 2019, p. 21-37.

Copeland, Roger, et Cohen, Marshall (dir.), What is Dance? Readings in Theory and Criticism, Oxford \& New York, Oxford University Press, 1983.

Derail, Agnès, et Roudeau, Cécile, Whitman, Feuille à feuille, Paris, Presses de l'ENS, 2019.

Duncan, Isadora, My Life [1927] New York \& London, Liveright Publishing, 2013.

Duncan, Isadora, « The Dancer of the Future », in Roger Copeland \& Marshall Cohen (dir.), What is Dance? Readings in Theory and Criticism, Oxford \& New York, Oxford University Press, 1983, p. 262-264.

Jucovy, Beth, et Romaine, Shirley. «I hear America singing, I see America dancing », compagnie Dance Visions, première représentation à la Jericho Library, New York, avril 2019.

Killingsworth, Jimmie, Whitman's Poetry of the Body; Sexuality, Politics, and the Text, Chapel Hill \& London, University of North Carolina Press, 1989.

Whitman, Walt, Leaves of Grass and Other Writings [1955] Michael Moon (dir.), New York, Norton, 2002. 


\section{NOTES}

1. "The Dancer of the Future » / " Der Tanz der Zukunft ", conférence donnée à Leipzig en 1903.

2. "Her step was free and elastic, and her voice sounded exquisitely as she spoke. / My mother look'd in delight and amazement at the stranger,/ She look'd at the freshness of her tall-borne face and full and pliant limbs » (Leaves of Grass, 361).

3. "Whitman's physicality implies a new understanding of beauty based on the health and vigor of the body " (Killingsworth J., 1989: 14). Killingsworth oppose la "moralité physique " à une "moralité sociale»; Whitman était un fervent défenseur de l'activité physique et rejetait l'oisiveté des classes sociales dites supérieures.

4. Voir Adeline Chevrier-Bosseau, «Dance in Walt Whitman's Leaves of Grass: Haptic Connectedness and Lyric Choreography », in Derail \& Roudeau, 21-37.

5. "I hear the Spanish dance with castanets in the chestnut shade », Leaves of Grass, 118.

6. " The child leaving his bed wander'd alone, bareheaded, barefoot, / Down from the shower'd halo, / Up from the mystic play of shadows twining and twisting as if they were alive, ", Leaves of Grass,

7. Duncan, qui avait grandi en Californie, s'est beaucoup inspirée du mouvement naturel des vagues dans sa danse.

8. Cet extrait du ballet n'a pas pu être dansé exceptionnellement lors de cet événement, mais il est habituellement dansé dans toutes les représentations.

\section{AUTEUR}

\section{ADELINE CHEVRIER-BOSSEAU}

Adeline Chevrier-Bosseau est Maitre de conférences et membre du CELIS (Centre de recherche sur les Littératures et la Sociopoétique) à l'Université Clermont-Auvergne.

Adeline.CHEVRIER_BOSSEAU@uca.fr 